\title{
Least limiting water range of Udox soil under degraded pastures on different sun-exposed faces
}

\author{
Renato Ribeiro Passos ${ }^{1}$, Liovando Marciano da Costa ${ }^{2}$, Igor Rodrigues de Assis ${ }^{2}$, Danilo Andrade \\ Santos $^{1}{ }^{*}$, Hugo Alberto Ruiz ${ }^{2}$, Lorena Abdalla de Oliveira Prata Guimarães ${ }^{3}$, and Felipe Vaz Andrade \\ ${ }^{1}$ Center for Agricultural Sciences and Engineering, Federal University of Espírito Santo, Alto universitário, 29500-000, \\ Alegre, ES, Brazil \\ ${ }^{2}$ Soil Science Department, Federal University of Viçosa, Av. P.H. Rolfs, 36570-000, Viçosa, MG, Brazil \\ ${ }^{3}$ Rural Development Regional Center Centro Serrano, Capixaba Institute of Research, Technical Assistance and Rural Extension - \\ Incaper, BR 262 - km 94, 29375-000, Venda Nova do Imigrante, ES, Brazil
}

Received October 4, 2016; accepted June 19, 2017

\begin{abstract}
A b s t r a c t. The efficient use of water is increasingly important and proper soil management, within the specificities of each region of the country, allows achieving greater efficiency. The South and Caparaó regions of Espírito Santo, Brazil are characterized by relief of 'hill seas' with differences in the degree of pasture degradation due to sun exposure. The objective of this study was to evaluate the least limiting water range in Udox soil under degraded pastures with two faces of exposure to the sun and three pedoenvironments. In each pedoenvironment, namely Alegre, Celina, and Café, two areas were selected, one with exposure on the North/West face and the other on the South/ East face. In each of these areas, undisturbed soil samples were collected at $0-10 \mathrm{~cm}$ depth to determine the least limiting water range. The exposed face of the pasture that received the highest solar incidence (North/West) presented the lowest values in least limiting water range. The least limiting water range proved to be a physical quality indicator for Udox soil under degraded pastures.

K e y w o r d s: soil quality, degraded soils, soil physics
\end{abstract}

\section{INTRODUCTION}

The current decade, eventually, will be marked by the water crisis, and the efficient use of water will become increasingly important. In such scenario, the soil plays a major role, being a part of the hydrological cycle and constituting the sphere capable of management. In this sense, the efficient management of the soil, given the particularities of each region of the country, is fundamental for the sustainability of agriculture.

*Corresponding author e-mail: danilo_as@live.com
In the South and Caparaó regions of the State of Espírito Santo (SEAG, 2008) where the watershed of the Alegre River is located, problems related to pasture degradation are critical due to natural factors and the anthropic performance. The region is also characterized by relief of hill seas - a geomorphological aspect described by Ab'saber (1970) - that generates another conditioning factor, exposure to the sun, which influences the observable differences in pasture degradation state.

The visually observed discrepancies between the faces of exposure are, amongst multiple factors, due to the indirect effects of the interception of the solar rays, effects which are variable depending on orientation of the slopes and the translation and rotation movements of the Earth. In the southern hemisphere, the north-facing slopes tend to receive higher incidence than those facing the South (Ferreira et al., 2005).

On a local scale, incident solar radiation is strongly influenced by topography, mainly represented by the shape of the terrain, slope, and orientation of the face of exposure. Consequently, variations in soil temperature, energy balance, and solar radiation influence the dynamics of soil physical factors (in addition to chemical and biological factors) and, as a result, play a role in conditioning plant development (Letey, 1985) within the soil-plantatmosphere system. Thus, the interaction of these three components, among other factors, may have an impact on the soil structure.

(C) 2017 Institute of Agrophysics, Polish Academy of Sciences 
Changes in the soil structure lead to changes in the pore space architecture available for root development, aeration, and water availability to the plants, in addition to inducing changes in soil resistance to root penetration in regards to both space and time (Moreira et al., 2014; Tormena et al., 2007). There is, therefore, a complex link between soil structure, daily and annual solar radiation regimes, and plant development that reflect effects on the physical quality of cultivated soils.

Different determinations and indices have been used to evaluate the physical quality of cultivated soils, among which the least limiting water range (LLWR) is highlighted. The LLWR integrates effects of water potential on soil, mechanical resistance to root penetration, and soil porosity adequate to the diffusion of oxygen to the roots as a function of soil density for samples representing a given area (Silva et al., 1994). This index has also shown strong sensitivity to soil structural indexes such as soil density and relative density, as well as being used in other models to characterize water availability (Asgarzadeh et al., 2011).

The LLWR has been used as a tool to indicate the limitations and potentialities of soil physical conditions to plant development, including in pastures (Leão et al., 2004; Lima et al., 2012) and in comparisons between pastures and other land uses (Lima et al., 2009). It is also effective as an indicator of changes in the structure of latosols (Lima et al., 2012; Severiano et al., 2011), which best translates physical edaphic quality to plants (Tormena et al., 2007).

Thus, the objective of this work was to evaluate the alterations of the least limiting water range of latosols under degraded pastures in three pedoenvironment and two faces of exposure to the sun in the watershed of the Alegre river.

\section{MATERIAL AND METHODS}

The study area is located in the areas defined in PEDEAG as South and Caparaó in the State of Espírito Santo - Brazil (SEAG, 2008). In this region, studies were carried out in the sub-basin of the Alegre River, located in the city of Alegre-ES, and inserted in the watershed of the Itapemirim river. In this sub-basin, according to the predominance of the relief aspect, three pedoenvironment were separated:

- pedoenvironment Alegre, delimited between 118 and $400 \mathrm{~m}$ of altitude;

- pedoenvironment Celina, delimited between 400 and $700 \mathrm{~m}$ altitude; and

- pedoenvironment Café, delimited between 700 and $1242 \mathrm{~m}$ altitude. In each pedoenvironment, areas with degraded brachiaria pastures were selected in Udox soils and two distinct faces of exposure to the sun: North/West and South/East.
In each pedoenvironment and face of exposure to the sun, thirty undisturbed soil samples were collected in a volumetric ring at $0-10 \mathrm{~cm}$ depth using a Uhland type sampler with three replicates.

The volumetric water content $(\theta)$ was determined for the $-4,-6,-8,-10,-30,-50,-70,-100,-500$, and $-1500 \mathrm{kPa}$ matrix potentials to establish the soil water retention curve (SWRC), using three undisturbed soil samples for each potential. Immediately after reaching equilibration with the pressure plates extractor, the samples were weighed and submitted to static laboratory penetrograph to establish a curve for resistance of soil to penentration (CRP). The penetrograph (Marconi MA 933) is composed of a linear electric actuator with stepper motor, a panel for controlling speed and direction of travel, and a load cell with nominal capacity of $20 \mathrm{~kg}$ coupled to the end of the mechanical arm of the actuator. It also has a metal rod with a diameter of $6 \mathrm{~mm}$ and the end has a cone that was used to determine the soil resistance to penetration. The penetration velocity was equal to $10 \mathrm{~mm} \mathrm{~min}^{-1}$ at $5 \mathrm{~cm}$ depth.

The samples were then dried in an oven at $105^{\circ} \mathrm{C}$ for $24 \mathrm{~h}$ to obtain soil moisture and soil density $(B d)$. The total porosity ( $\mathrm{Tp}$ ) was calculated by the expression $\mathrm{Tp}=1-B d / \mathrm{Pd}$, where the mean value of particle density (Pd) was obtained by the volumetric balloon method (EMBRAPA, 2011).

The physical characterization of the soil samples of the different pedoenvironments and faces of exposure to the sun consisted of granulometric analysis and determination of total porosity, macroporosity, and microporosity (EMBRAPA, 2011) (Table 1).

To obtain the LLWR, the results obtained from SWRC and CRP were considered. The SWRC was obtained by adjusting the values of $\theta$ as a function of soil matrix potential ( $\Psi)$, according to Silva et al. (1994) as described by Eq. (1):

$$
\theta=a \Psi^{b} B d^{c},
$$

where: $\theta$ is the volumetric water content $\left(\mathrm{m}^{3} \mathrm{~m}^{-3}\right), \Psi$ is the soil matrix potential $(\mathrm{kPa}), B d$ is the soil density $\left(\mathrm{Mg} \mathrm{m}^{-3}\right)$; and $a, b$, and $c$ were the model adjustment parameters (Table 2).

The CRP was adjusted to nonlinear models as a function of Bd (Busscher, 1990; Silva et al., 1994), according to Eq. (2):

$$
P R=d \theta^{e} B d^{f},
$$

where: $P R$ is the resistance to penetration $(\mathrm{kPa}), \theta$ is the volumetric water content $\left(\mathrm{m}^{3} \mathrm{~m}^{-3}\right), B d$ the soil density $(\mathrm{Mg}$ $\left.\mathrm{m}^{-3}\right)$; and $d, e$, and $f$ are the adjustment parameters of the equation (Table 2).

The LLWR was determined by adopting the procedures described by both Silva et al. (1994) and Tormena et al. (1998), modifying the limit of soil mechanical resistance to penetration. The critical values of soil water content associated with the matric potential, soil resistance to penetration, 
T a b l e 1. Physical characterization of soil of pedoenvironments Alegre, Café and Celina, for the East/South (E/S) and North/West (N/W) sun exposure faces

\begin{tabular}{|c|c|c|c|c|c|c|c|}
\hline \multirow{2}{*}{ Characteristic } & \multirow{2}{*}{ Unit } & \multicolumn{2}{|c|}{ Alegre } & \multicolumn{2}{|c|}{ Café } & \multicolumn{2}{|c|}{ Celina } \\
\hline & & $\mathrm{E} / \mathrm{S}$ & $\mathrm{N} / \mathrm{W}$ & $\mathrm{E} / \mathrm{S}$ & $\mathrm{N} / \mathrm{W}$ & $\mathrm{E} / \mathrm{S}$ & $\mathrm{N} / \mathrm{W}$ \\
\hline Clay & & 0.463 & 0.370 & 0.320 & 0.380 & 0.537 & 0.523 \\
\hline Silt & $\left(k \sigma \in k^{-1}\right)$ & 0.103 & 0.153 & 0.107 & 0.070 & 0.117 & 0.117 \\
\hline Coarse sand & & 0.317 & 0.347 & 0.470 & 0.377 & 0.253 & 0.250 \\
\hline Fine sand & & 0.117 & 0.130 & 0.103 & 0.173 & 0.093 & 0.110 \\
\hline Total porosity & & 0.418 & 0.381 & 0.361 & 0.446 & 0.479 & 0.455 \\
\hline Macroporosity & $\left(m^{3} m^{-3}\right)$ & 0.060 & 0.012 & 0.022 & 0.087 & 0.034 & 0.043 \\
\hline Microporosity & & 0.358 & 0.369 & 0.339 & 0.359 & 0.445 & 0.412 \\
\hline Ground declivity & $(\%)$ & 25 & 45 & 28 & 38 & 28 & 27 \\
\hline
\end{tabular}

T a b l e 2. Linear regression parameters estimates for soil resistance to penetration $(P R, \mathrm{MPa})$, as a function of the volumetric water content $\left(\theta, \mathrm{m}^{3} \mathrm{~m}^{-3}\right)$ and soil density $\left(B d, \mathrm{Mg} \mathrm{m}^{-3}\right)$; and for the soil water content $\left(\theta, \mathrm{m}^{3} \mathrm{~m}^{-3}\right)$ as a function of soil density $\left(B d, \mathrm{Mg} \mathrm{m} \mathrm{m}^{-3}\right)$ and matric potential $(\Psi, \mathrm{MPa})$

\begin{tabular}{|c|c|c|c|c|c|c|c|c|c|}
\hline \multirow{3}{*}{\multicolumn{2}{|c|}{ Pedoenvironment }} & \multicolumn{8}{|c|}{ Parameters } \\
\hline & & \multicolumn{3}{|c|}{$P R=d \theta^{\mathrm{e}} B d^{f}$} & \multirow{2}{*}{$\mathrm{R}^{2}$} & \multicolumn{3}{|c|}{$\theta=a \Psi^{b} B d^{c}$} & \multirow{2}{*}{$\mathrm{R}^{2}$} \\
\hline & & $d$ & $e$ & $f$ & & $a$ & $b$ & $c$ & \\
\hline \multirow{2}{*}{ Alegre } & $\mathrm{E} / \mathrm{S}$ & 0.107 & -1.400 & 4.830 & 0.50 & -1.884 & 0.369 & -0.057 & 0.60 \\
\hline & $\mathrm{N} / \mathrm{W}$ & 0.343 & -1.185 & 2.188 & 0.41 & -1.011 & -0.210 & -0.070 & 0.71 \\
\hline \multirow{2}{*}{ Café } & $\mathrm{E} / \mathrm{S}$ & 0.029 & -1.756 & 5.693 & 0.56 & -1.279 & -0.180 & -0.075 & 0.64 \\
\hline & $\mathrm{N} / \mathrm{W}$ & 0.005 & -2.653 & 8.504 & 0.70 & -2.927 & 0.975 & -0.088 & 0.84 \\
\hline \multirow{2}{*}{ Celina } & $\mathrm{E} / \mathrm{S}$ & 0.177 & -2.46 & 1.170 & 0.49 & -1.857 & 0.566 & -0.065 & 0.91 \\
\hline & $\mathrm{N} / \mathrm{W}$ & 0.112 & -2.044 & 4.125 & 0.75 & -1.740 & 0.305 & -0.082 & 0.88 \\
\hline
\end{tabular}

and aeration porosity were, respectively, moisture in the field capacity $\left(\theta_{F C}\right)$ or estimated water content in the potential of $-10 \mathrm{kPa}$; the moisture at the permanent wilting point $\left(\theta_{P W P}\right)$ or water content at the potential of $-1500 \mathrm{kPa}$; the limit of the mechanical resistance of soil penetration $\left(\theta_{P R}\right)$ or the water content where the penetration resistance limit reaches a value of $3.0 \mathrm{MPa}$ - value chosen based on the work of Lipiec and Hakansson (2000); and the soil water content in which the aeration porosity $\left(\theta_{A P}\right)$ is $0.10 \mathrm{~m}^{3} \mathrm{~m}^{-3}$ (AP), corresponding to $10 \%$ of the total porosity.

The upper limits of the LLWR were defined according to the $\theta_{F C}$, or $\theta_{A P}$ when pertinent and is considered adequate, for the growth and development of the culture $\left(0.10 \mathrm{~m}^{3} \mathrm{~m}^{-3}\right)$. For the lower limits, the $\theta_{P W P}$, or for situations corresponding to the $\theta_{P R}$, is limiting the growth and development of the plants, were considered in accordance with the adopted critical level (3.0 MPa). The critical soil den- sity $(B d c)$, which corresponds to the value of $B d$ at which the LLWR is equal to zero and there is an intersection of the upper and lower limits (UL and LL, Respectively) (Silva et al., 1994), was obtained by the Excel solver function, using the algorithm proposed by Leão and Silva (2004). Using excel, equations that relate the variables $\theta_{F C}, \theta_{P W P}$, $\theta_{A P}$, and $\theta_{P R}$ with the $B d$ were developed as a function of the cell with the value of $B d$ that is optimized for the value of $B d c$. Another cell with the UL - LL (LLWR) value also needed to be created. Using the solver causes the target cell to become the cell with the value of UL - LL. The 'min' option is activated and the 'cell change' will be the contents of the cell with the value of $B d$. This step also adds a restriction relative to the cell resulting from $\mathrm{UL}-\mathrm{LL}$ that prevents it from being less than zero and ensures that the $B d c$ will be equal to the value of $B d$ (Leão and Silva, 2004). 


\section{RESULTS AND DISCUSSION}

As the density of the Udox soil increased, there was also an increase in the $P R$ values and reduction of aeration porosity (Fig. 1). Similar behavior was observed by both Silva et al. (1994) working with silty loam type soil (USDA soil texture classification, 1993) from Canada and Tormena et al. (1998) in a Oxisoil under no-tillage. The soil solids approach to the same volume, a phenomenon that results in increased soil density, is caused by animal trampling (Tarrá et al., 2010), the passage of implements
(Tormena et al., 1998), or even pedogenesis (Dantas et al., 2014), which directly influences the quantity and quality of soil pore volume and soil resistance to root penetration (Silva et al., 2006).

It is expected that as the soil density increases, the values of resistance to root penetration increase and the pore space will be altered, especially the volume of macropores that are responsible for the drainage of water and air flow in the soil. Silva et al. (2006) also observed there is a negative correlation between macroporosity and soil density a

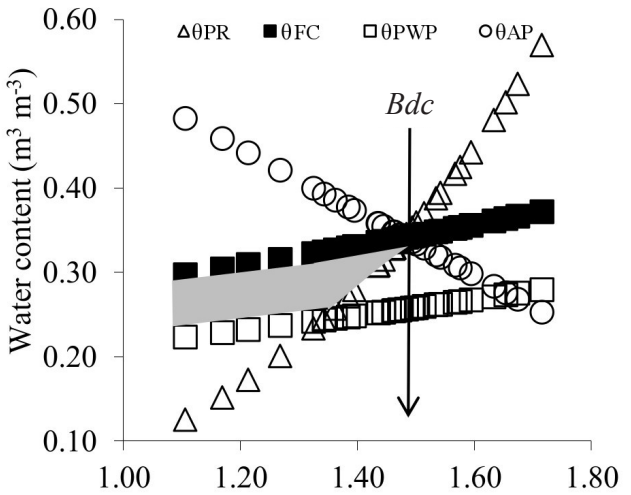

b

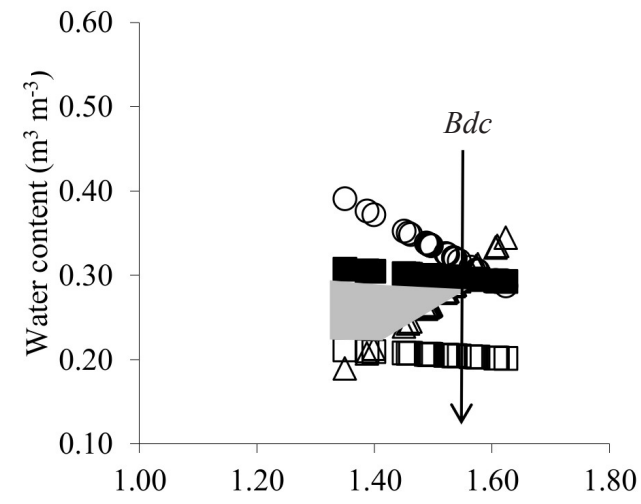

$\mathrm{c}$

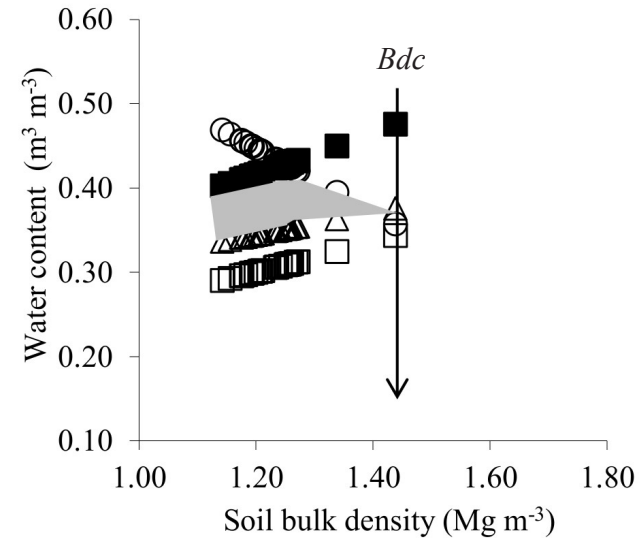

d

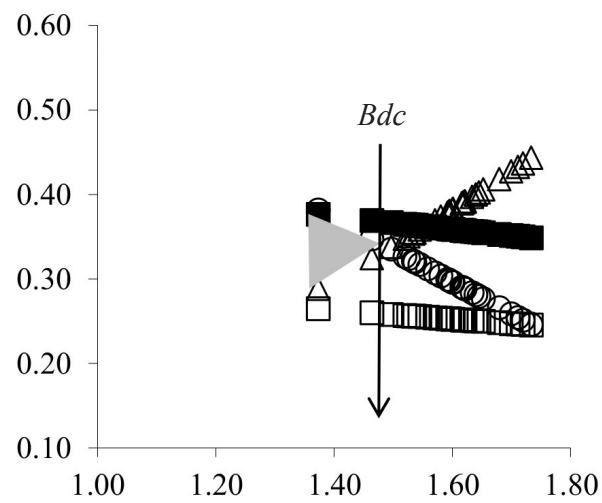

e

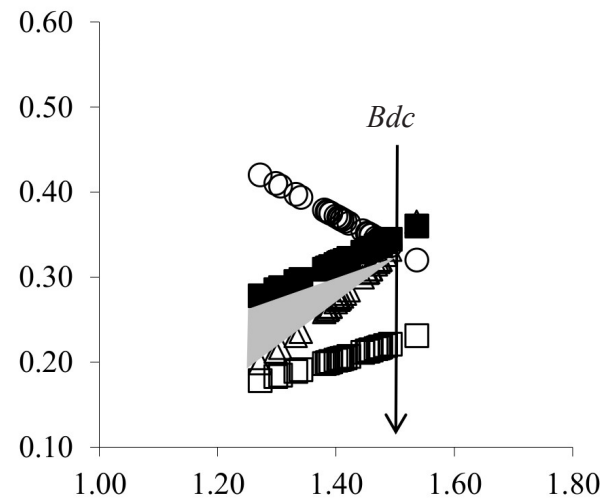

f

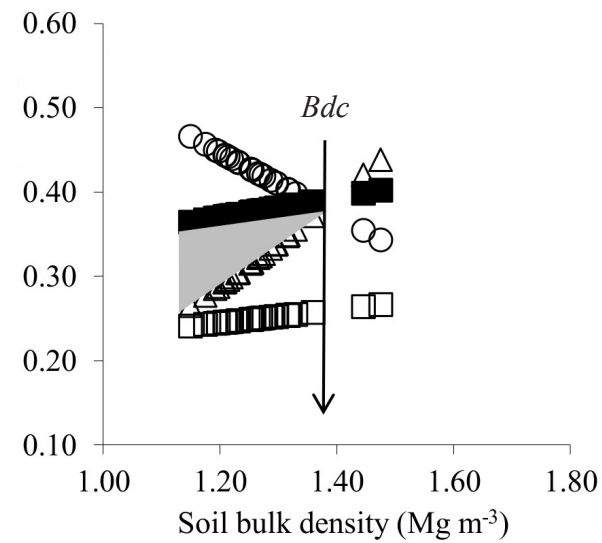

Fig. 1. Water content variation with soil density at critical levels of field capacity (FC), $\Psi=-0.01 \mathrm{MPa}$, wilting point (PWP), $\Psi=$ $-1.5 \mathrm{MPa}$, aeration porosity (AP) of $10 \%$ and penetration resistance $(P R)$ of $3.0 \mathrm{MPa}$ for pedoenvironments: a - Alegre, South/East face; $\mathrm{b}$ - Café, South/East face; c - Celina, South/East face; d - Alegre, North/West face; e - Café, North/West face, and f - Celina, North/ West face. $B d c-$ soil critical density. The grey areas represents the LLWR. 
and soil penetration resistance. Given the proximity of the soil particles and aggregates and the reduction of available space for both root growth and for the displacement of soil solids as a response to root growth, soil aggregates resist the growth of underground plant organs.

The northern facing slopes in the southern hemisphere tend to receive higher irradiance than those facing the South. Thus, considering the same type of soil on the North face, it is expected that the wetting and drying cycles are more intense, and the soil cover, microbial activity, and organic matter accumulation are lower because water contents are lower and soil surface temperatures are higher, as also discussed by Chagas et al. (2013). Consequently, slope soils facing the North/West tend to be less physically unfavorable for the development and productivity of plants than those of the South/East face, especially for the surface layers. The current study reaffirmed this finding through the LLWR for the $0-10 \mathrm{~cm}$ layer in all the pedoenvironments.

In the Alegre pedoenvironment, the left shift and narrowing LLWR clearly demonstrated the inferior soil physical conditions on the North/West face (Fig. 1). In the other pedoenvironments, there was no movement and narrowing of the LLWRs in such a way, but the lower values of $B d c$ on the North/West face suggest more restricted conditions for the development of plants. Above $1.52 \mathrm{Mg} \mathrm{m}^{-3}$ for Café and $1.38 \mathrm{Mg} \mathrm{m}^{-3}$ for Celina, regardless of water content, soil physical conditions are not favorable to plants. Differently, on the South/East face of exposure, conditions are still favorable under values of $B d$ close to $1.55 \mathrm{Mg} \mathrm{m}^{-3}$ in the Café and $1.44 \mathrm{Mg} \mathrm{m}^{-3}$ in Celina. In the Celina pedoenvironment, this difference is even more pronounced. Physical conditions are adequate even with $B d$ varying from 1.38 to $1.44 \mathrm{Mg} \mathrm{m}^{-3}$, depending on soil water content on the South/ East side. Thus, lower $B d$ values are already limiting to the development of plants on the North/West face. On the other hand, the soils on the South/East face may present slightly higher values of $B d$, yet the physical conditions may be favorable to the plants.

In the Alegre pedoenvironment on the South/East face (Fig. 1a), the lower limit of the LLWR is changed from the moisture $\theta_{P W P}$ to the $P R$ for the values of $B d>1.32 \mathrm{Mg}$ $\mathrm{m}^{-3}$. This means that under lower $B d$ values, $P R$ becomes a problem only in very low water contents and the main limiting factor for plant growth is the amount of water available to the plants. In relation to the upper limit of the LLWR on the South/East face (Fig. 1a), the $\theta_{A P}$ replaces the humidity $\theta_{F C}$ for values of $B d>$ critical soil density $(B d c)$, as in the case of values greater than $1.47 \mathrm{Mg} \mathrm{m}^{-3}$. Thus, for values of $B d<1.47 \mathrm{Mg} \mathrm{m}^{-3}$, the pasture will not have its development limited by the reduced diffusion of oxygen in the soil. This will only occur if the water content is quite high, filling more than $90 \%$ of the porous space of the soil. On the North/West face (Fig. 1d) where $B d c$ presented a value of $1.48 \mathrm{Mg} \mathrm{m}^{-3}$, the $\theta_{A P}$ was the upper limit of the LLWR for values of $B d>1.35 \mathrm{Mg} \mathrm{m}^{-3}$, demonstrating the importance of water retention at lower potentials. It should also be noted that in the Alegre pedoenvironment on this face, $93.3 \%$ of the samples presented LLWR equal to zero.

When examining the soil of the Café pedoenvironment on the South/East face, it can be verified that the upper limit of the LLWR is determined by the $\theta_{F C}$ for the entire range of $B d$ where the LLWR has a value greater than zero (Fig. 1b). It is also shown that for values of $B d>1.40 \mathrm{Mg} \mathrm{m}^{-3}$, the lower limit of the LLWR stops being the $\theta_{P W P}$ and becomes the $P R$. During this time, the LLWR reduces drastically to the $B d c$ of the soil. On the North/West face, the $B d c$ was $1.51 \mathrm{Mg} \mathrm{m}^{-3}$, showing a reduction of the LLWR in comparison to the South/East face.

In the Celina pedoenvironment on the South/East face, the lower limit of the LLWR is determined by the $P R$ across the $B d$ range (Fig. 1c). At the upper limit, the $\theta_{A P}$ replaces the $\theta_{F C}$ for values of $B d>1.25 \mathrm{Mg} \mathrm{m}^{-3}$. On the North/West face (Fig. 1f), $\theta_{A P}$ constitutes the upper limit of the LLWR for values of $B d>1.35 \mathrm{Mg} \mathrm{m}^{-3}$. The critical soil density $(B d c)$ for the South/East face soil is $1.44 \mathrm{Mg} \mathrm{m}^{-3}$ (Fig. 1c), and for the North/West face, it is $1.38 \mathrm{Mg} \mathrm{m}^{-3}$ (Fig. 1f).

The lower limit of the water content on the North/ West faces of exposure of all evaluated pedoenvironments was defined by $P R$. This demonstrates that for areas that receive higher solar incidence, the $P R$ starts to assume an even more important role in the availability of water under low potentials. It is important to note that the values of $P R$ reduce with increased soil moisture due to the lubricating effect of the water, which reduces the cohesion between the particles in the soil matrix. On the other hand, the approximation of the solid particles of the soil, by means of compaction, raises the values of mass in a similar volume, which results in a greater interparticle cohesion or friction (Vepraskas, 1984) and, thus, results in greater resistance of the soil to the penetration of roots. The lower limit was not determined by the $P R$ on the South/East faces of the Alegre and Café pedoenvironments (for lower values of $B d$ ). In the Celina pedoenvironment, the $P R$ was the lower limit for both faces, possibly due to the greater interference of the animal activity in pastures (bovine trampling). This due to its greater susceptibility to compaction because it has higher clay contents compared to other areas (Table 1).

The LLWR was positively correlated with the $B d$ values of 1.35 and $1.25 \mathrm{Mg} \mathrm{m}^{-3}$ for the soils on the South/ East face in the Alegre and Celina pedoenvironments, respectively (Fig. 2). Tormena et al. (1998) and Severiano et al. (2011) observed similar behavior when working with clay textured Oxisoils (USDA soil texture classification, 1993). This behavior can be explained by the occurrence of the granular structure for oxidic soils, increasing the porous aeration space (Severiano et al., 2011), which increases the LLWR amplitude in a positive way. The phenomenon can be explained by the approximation and rearrangement of the solid particles, which allows the development of smaller size 

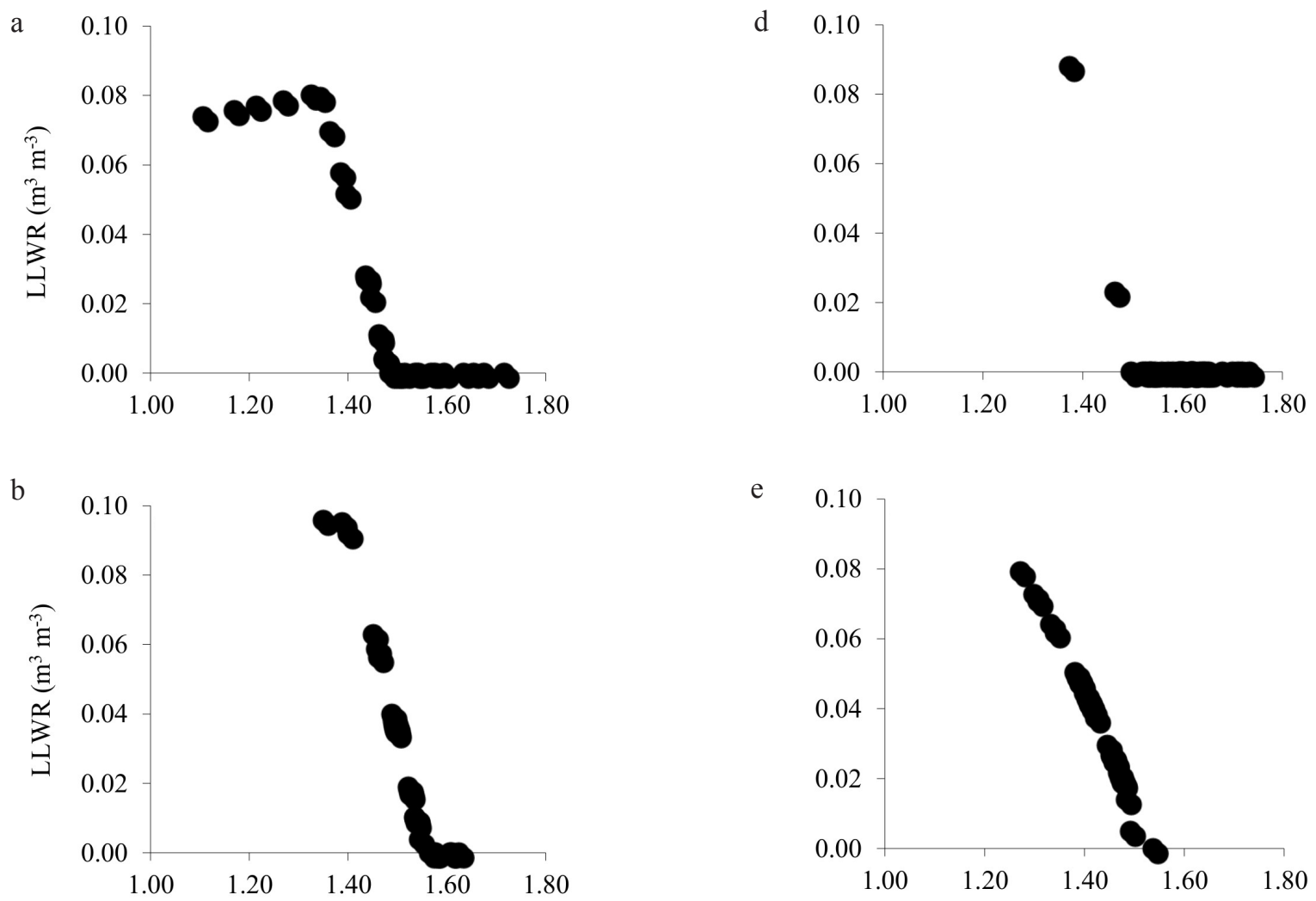

e
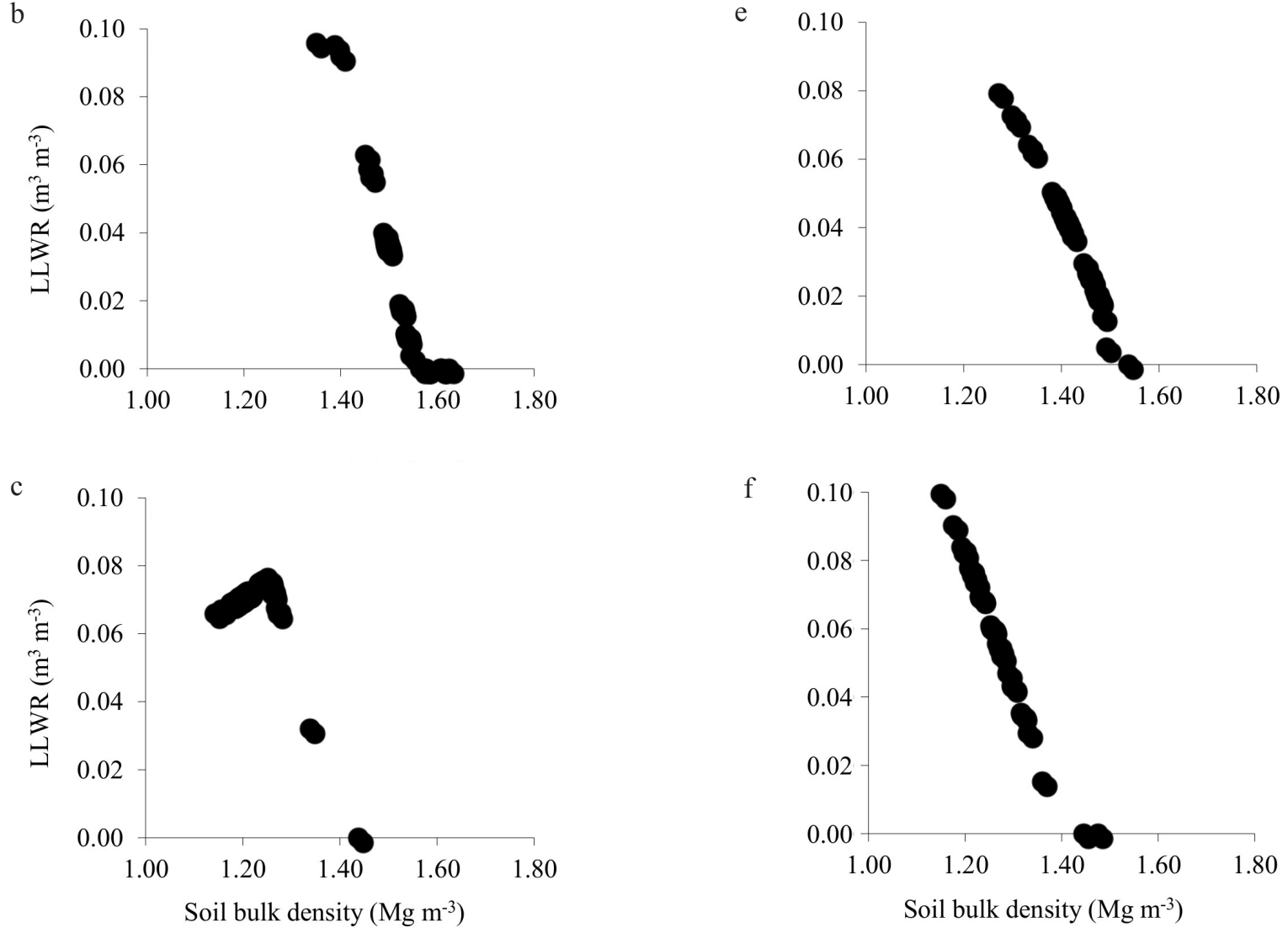

Fig. 2. Variation of least limiting water range depending on soil density for pedoenvironments: $a-$ Alegre, South/East face; $b$ - Café, South/East face; c - Celina, South/East face; d-Alegre, North/West face; e - Café, North/West face and f - Celina, North/West face.

pores to the detriment of larger diameter pores (such as porous aeration space). This increases the $\theta$ retained at higher tensions, replacing pre-existing aeration porosity. It should be emphasized that if the proximity of the soil solid phase results in a minimum or limit of porous space, which tends to occur under greater compressions, the consequences would be contrary. Thus, with reduction of the pore volume, there wold be losses of the volume of storage of water, a process that explains the reduction of the LLWR to higher values of soil density at certain limits observed for this attribute.
The LLWR of the soil in the Café pedoenvironment for the South/East face did not vary until the $B d$ of $1.40 \mathrm{Mg} \mathrm{m}^{-3}$. At this value, there was a reduction of the LLWR, resulting in zero from values of $B d \geq 1.54 \mathrm{Mg} \mathrm{m}^{-3}$ onward (corresponding to $B d c$ ) (Fig. 2b).

The importance of LLWR in relation to the face of exposure of higher solar incidence (North/West) can be verified in Fig. 2d, e, and $\mathrm{f}$. It is noticed that the availability of water in the soil is reduced to the proportion that the density of the soil increases, being $93.3 \%$ for the samples. In the case of the Alegre pedoenvironment, the LLWR presented equal to zero, which occurs for values of $B d>1.48$ $\mathrm{Mg} \mathrm{m}^{-3}$ (Fig. 2d). 
From the climatic point of view, the exposure to higher solar incidence, promoted by the position of the slopes in the landscape, generates greater losses of soil water by evapotranspiration and reduces the development of grasses. If water requirements are not met, there will also be an increase in soil resistance to root penetration due to lower soil moisture (Bengough et al., 2011). Consequently, there is a reduction in both root and shoot development of grasses (Masle and Passioura, 1987). Without proper root development, the system loses the potential to produce biopores in the soil (Magalhães et al., 2009; Severiano et al., 2010; Calonego et al., 2011; Lima et al., 2012) and provide organic material (Fidalski et al., 2010), which are two important phenomena for the development and improvement of soil structure and physical quality (Andrade et al., 2009), including deep layers (Calonego et al., 2011). Works such as that of Leão et al. (2004), Lima et al. (2012), and Flávio Neto et al. (2015) emphasize the importance of adequate management of pastures and their effects under the conditions necessary for plant development in the LLWR available to the plants.

\section{CONCLUSIONS}

1. The least limiting water range for the soil is influenced by the face of exposure to the sun. The face of exposure that receives the highest incident solar radiation (North/West) presented lower values for the least limiting water range.

2. Lower altitude pedoenvironments, like the Alegre pedoenvironment, tend to suffer greater effects on the degradation of pastures, mainly due to the consequent effect of higher temperatures.

3. The least limiting water range has been shown to be a sensitive indicator of physical quality of Oxisols under degraded pastures.

Conflict of interest: The Authors do not declare conflict of interest.

\section{REFERENCES}

Ab'saber A.N., 1970. Geological provinces and morphoclimatic domains in Brazil (in Portuguese). Geomorfologia, 20, 1-26.

Andrade R.S., Stone L.F., and Silveira P.M., 2009. Cover crops and physical quality of an Oxisol under no-tillage (in Portuguese). Revista Brasileira de Engenharia Agrícola e Ambiental, 13, 411-418.

Asgarzadeh H., Mosaddeghi M.R., Mahboubi A.A., Nosrati A., Dexter A.R., 2011. Integral energy of conventional available water, least limiting water range and integral water capacity for better characterization of water availabiity and soil physical quality. Geoderma 166, 34e4

Bengough A.G., McKenzie B.M., Hallett P.D., and Valentine T.A., 2011. Root elongation, water stress and mechanical impedance: a review of limiting stresses and beneficial root tip traits. J. Experimental Botany, 62, 59-68.
Busscher W.J., 1990. Adjustment of flat-tipped penetrometer resistance data to a commom water content. Trans. American Society Agric. Eng., 33, 519-524.

Calonego J. C., Borghi E., and Crusciol C.A.C., 2011. Optimum water interval and soil compaction with intercropped corn and brachiaria (in Portuguese). Revista Brasileira de Ciência do Solo, 35, 2183-2190.

Chagas C. da S., Fontana A., Junior W. de C., Caires S.M. de, 2013. Topographical attributes in the differentiation of Argisols (in Portuguese). Revista Brasileira de Ciência do Solo, 37, 1441-1453.

Dantas J.S., Júnior J.M., Filho M.V.M., Resende J.M. do A., Camargo L.A., and Barbosa R.S., 2014. Genesis of cohesive soils of the East Maranhense: relation soil landscape (in Portuguese). Revista Brasileira de Ciência do Solo, 38, 1039-1050.

EMBRAPA, 2011. Brazilian Agricultural Research Corporation. Manual of methods of soil analysis (in Portuguese). Ministry of Agriculture and Supply, Rio de Janeiro, Brasil.

Ferreira F.P., Azevedo A.C. de, Wappler D., Kanieski A.J., Girelli D., and Pedrotti J., 2005. Solar exposition and soil properties in Santa Maria - RS (in Portuguese). Revista Brasileira de Agrociência, 11, 377-381.

Fidalski J., Tormena C.A., and Silva Á.P., 2010. Least limiting water range and physical quality of soil under groundcover management systems in citrus. Scientia Agricola, 67, 448-453.

Flávio Neto J., Severiano E.C., Costa K.A.P., Guimarães Junior, W.S., Goncalves W.G., and Andrade R., 2015. Biological soil loosening by grasses from genus Brachiaria in crop-livestock integration. Acta Scientiarum. Agronomy, 37, 375-383.

Leão T.P. and Silva A.P., 2004. A simplified Excel ${ }^{\circledR}$ algorithm for estimating the least limiting water range of soils. Scientia Agricola, 61, 649-654.

Leão T.P., Silva A.P., Macedo M.C.M., Imhoff S., and Euclides V.P.B., 2004. Optimum water interval in the evaluation of continuous and rotational grazing systems (in Portuguese). Revista Brasileira de Ciência do Solo, 28, 415-423.

Letey J., 1985. Relationship between soil physical properties and crop reduction. Advances in Soil Science, 1, 277-294.

Lima V.M.P., Oliveira G.C. de, Serafim M.E., Curi N., and Evangelista A.R., 2012. Optimum water interval as indicator of improvement of the structural quality of degraded latosol (in Portuguese). Revista Brasileira de Ciência do Solo, 36, 71-78

Lima V.M.P., Oliveira G.C. de, Severiano E. da C., and Oliveira L.F.C. de, 2009. Optimum water range and porosity of soils cultivated in an area of environmental protection in the south of Minas Gerais (in Portuguese). Revista Brasileira de Ciência do Solo, 33, 1087-1095.

Lipiec J. and Hakansson I., 2000. Influences of degree of compactness and matric water tension on some important plant growth factors. Soil Till. Res., 53, 87-94.

Magalhães E.N., Oliveira G.C. de, Severiano E. da C., Costa K.A. de P., and Castro M.B. de, 2009. Structural recovery and yield of Tifton 85 grass in a compacted Red-Yellow Argisol (in Portuguese). Ciência Animal Brasileira, 10, 68-76. 
Masle J. and Passioura J.B., 1987. The effect of soil strength on the growth of young wheat plants. Australian J. Plant Physiology, 14, 643-656.

Moreira F.R., Dechen S.C.F., Silva Á.P. da, Figueiredo G.C., Maria I.C. de, and Terezinha P., 2014. Optimum water interval in a red Latosol cultivated in a no-tillage system for 25 years (in Portuguese). Revista Brasileira de Ciência do Solo, 38, 119-127.

SEAG, 2008. State Secretariat for Agriculture, Supply, Aquaculture and Fisheries (in Portuguese). Strategic Plan for the Development of Agriculture Capixaba: new PEDEAG 2007-2025 / State Secretariat for Agriculture, Supply, Aquaculture and Fisheries - Vitória, Brasil.

Severiano E.C., Oliveira G.C., Junior M.S.D., Costa K.A.P., Castro M.B., and Magalhães E.N., 2010. Potential of the decomposition of an Argisol promoted by tifton grass 85 (in Portuguese). Brazilian J. Agric. Environ. Eng., 14, 39-45.

Severiano E.C., Oliveira G.C. de, Júnior, M. de S. D., Costa K.A. de P., Silva F.G., and Filho S.M.F., 2011. Structural changes in Latosols representative of the Cerrado Region: I - Relationships between soil physical attributes and least limiting water range. Revista Brasileira de Ciência do Solo, 35, 773-782.

Silva A.P., Kay B.D., and Perfect E., 1994. Characterization of the least limiting water range. Soil Sci. Soc. America J., 58, 1775-1781.
Silva S.R., Barros N.F., and Costa L.M., 2006. Atributos físicos de dois Latossolos afetados pela compactação do solo. Revista Brasileira de Engenharia Agrícola e Ambiental, 10, 842-847.

Tarrá I.L.C., Luizão F. de J., Wandelli E.V., Teixeira W.G., Morais W.J., and Castro J.G.D., 2010. Time of use in pastures and macropore volume of soil in Central Amazonia (in Portuguese). Revista Brasileira de Engenharia Agrícola e Ambiental, 14, 678-683.

Tormena C.A., Araújo M.A., Fidalski J., and Costa J.M. da, 2007. Temporal variation of the optimum water range of a dystroferric Red Latosol under no-till systems (in Portuguese). Revista Brasileira de Ciência do Solo, 31, 211-219.

Tormena C.A., Silva A.P., and Libardi P.L., 1998. Characterization of the optimum water range of a Red Latosol under no-tillage (in Portuguese). Revista Brasileira de Ciência do Solo, 22, 573-581.

USDA, 1993. Department of Agriculture. Soil Survey Division. Soil Conservation Service. Soil Survey Staff. Soil survey manual. Washington, (Agriculture Handbook, 18).

Vepraskas M.J., 1984. Cone index of loamy sands as influenced by pore size distribution and effective stress. Soil Sci. Society America J., 48, 1220-1225. 